MONIKA WIŚNIEWSKA-KIN

Uniwersytet Łódzki

\title{
Edukacyjny potencjał metody przekładu intersemiotycznego - propozycja dla nauczyciela
}

\section{Szansa w metodzie? O zniekształceniach w rozumieniu metody przekładu intersemiotycznego ${ }^{1}$}

Sprawne, świadome i refleksyjne posługiwanie się językiem oraz budowanie kultury literackiej jest wciąż niedocenionym, wręcz zaniedbanym obszarem w edukacji wczesnoszkolnej ${ }^{2}$. Na zajęciach w szkole coraz trudniej zainteresować uczniów tekstami poetyckimi, w których autorzy odrzucają przekazywanie prawd gotowych i oczywistych, skłaniając małego czytelnika do myślenia abstrakcyjnego. W trosce o dobre samopoczucie ucznia na lekcji nauczyciel zbyt często wybiera rozwiązania łatwe, rezygnując z zajęć wartościowych z punktu widzenia jakości złożonego procesu rozumienia i interpretacji tekstu literackiego. Opracowanie utworu literackiego jest często „technologią obróbki”, która nie służy ani dziełu, ani odbiorcy.

Inaczej, gdy stosuje się przekład intersemiotyczny. Zarówno walory psychologiczne metody, jak i dydaktyczne zdają się być niewątpliwe, pod warunkiem, że nie zostanie zniekształcona sama istota przekładu.

Chciałabym zaprosić do przemyślenia kwestii podstawowej: jak możemy organizować uczenie, żeby nie wpaść w pułapki i zasadzki wolności, z jakiej korzystamy. Praktyka pokazuje, że to niebezpieczeństwo jest realne. Taką uwodzicielska, powabną pokusa, o której łatwo sądzić, że uczyni nas nowoczesnymi nauczycielami, jest dowolność w rozumieniu i stosowaniu metod aktywnych ${ }^{3}, \mathrm{~m}$. in. metody przekładu intersemiotycznego.

$\mathrm{Z}$ potoku definicji, bezmiaru w rozumieniu metody wybrałam te podejścia, które przeciwstawiają się powodzi słów, tamują napływ rozmywającego

\footnotetext{
${ }^{1}$ Tekst jest rozszerzoną i zmienioną wersją artykułu zatytułowanego „Stan hibernacji” dziecięcych możliwości a ożywczy potencjat metody przekładu intersemiotycznego, który ukazał się w „Forum Oświatowym” 2010, nr 2 (43), s. 67-78.

${ }^{2}$ W. Żuchowska, Medice, cura te ipsum, „Nowa Polszczyzna” 2000, nr 5, s. 23.

${ }^{3}$ W. Żuchowska, Memento w sprawie metod, ,Nowa Polszczyzna” 2000, nr 3, s. 28.
} 
myślenia o metodzie. Przedstawię w zarysie koncepcje: Jana Polakowskiego, Alicji Baluch, Bożeny Chrząstowskiej i Wiesławy Żuchowskiej.

J. Polakowski odnosi przekład intersemiotyczny do tych sytuacji w komunikacji międzyludzkiej, w których te same treści staramy się przekazać przy pomocy różnych sposobów komunikowania: mowy, pisma, gestu, rysunku, dźwięku itd.

Nie jest przy tym rzecza obojętnq dla odbioru tej informacji, jaka droga zostanie ona przekazana. Każdy system semiotyczny odznacza się właściwa mu sprawnościq komunikowania i określonymi ograniczeniami w tym zakresie. (...) Poza tym każdy z nich wywiera określony wpływ na odbiorce, ksztattuje stosunek do komunikowanych treści, modyfikuje w swoisty sposób sens przekazywanych informacji. (...) Fakty te bierzemy pod uwagę, mówiac o celach zwiazanych z ksztatceniem kompetencji komunikacyjnych ucznia, czyli jego sprawności porozumiewania się $i$ znajomości różnych systemów znakowych ${ }^{4}$.

Więcej, jeśli w przekładzie uwzględnia się perspektywę odbiorcy, to koniecznie trzeba pamiętać o innym rodzaju percepcji i innym typie wrażliwości odbiorczej u współczesnych uczniów. Oswojeni ze specyfiką kultury audiowizualnej, której wyróżnikiem jest między innymi nasilenie zjawiska współwystępowania i współzależności różnych systemów semiotycznych, uczniowie ograniczają swój kontakt ze sztuką słowa.

Specyfika kultury wspótczesnej narzuca określone obowiazki edukacyjne [wyróżnienie M. W.-K.]. (...) Ponieważ przektady intersemiotyczne bez mała na co dzień towarzyszq aktom poznawczym wspótczesnego człowieka, zachodzi potrzeba upodabniania sytuacji szkolnych do tych, z którymi stykać sie będzie nasz wychowanek $w$ życiú .

Pracując z uczniem nie sposób nie uwzględnić jego upodobań do znaków kultury masowej i popularnej, która go otacza.

Perspektywę odbiorcy uwzględnia także A. Baluch. W analizie pozawerbalnej proponuje wykorzystać swoisty kształt świata dziecka, tzn. łatwość przekładu słowa na gest, barwę, kształt czy dźwięk.

Analiza ttumaczy się naturalnq tendencja dziecka do manifestowania swych uczuć w formie zachowań będacych ekspresjami różnych sztuk: śpiewu, tańca, malowania, zachowań zabawowych, a więc gier, wreszcie mówienia. (...) Przekłada więc obraz literacki na wypowiedź plastyczna, ruchowa (gestyczna, mimicznq) czy dźwiękowa (muzycznq lub recytacyjna), szukajac $w$ innych systemach znaków odpowiedników znaczeniowych, może bliższych mentalności dziecka ${ }^{6}$.

${ }^{4}$ J. Polakowski, Metoda przekładu intersemiotycznego w ksztatceniu sprawności językowej, „Oświata i Wychowanie” 1982, nr 17, s. 18-21.

${ }^{5}$ Tamże, s. 19.

${ }^{6}$ A. Baluch, Poezja wspótczesna w szkole podstawowej, Warszawa 1984, s. 15-17. 
Obcowanie z tą metodą rozwija u dzieci umiejętności kojarzenia różnych przedmiotów powiązanych jednością idei, pogłębia wrażliwość poprzez dźwiękowo-barwną metodę konkretyzacji utworów, usprawnia motorykę dziecka, opierając się na indywidualnej ekspresji, podbudowanej przeżyciami literackimi, uświadamia istnienie różnorodnych analogii i izomorfizmów w kulturze, rozwija wyobraźnię znakowa", stwarza wreszcie motywację manipulacyjna do wypowiedzi werbalnych ${ }^{7}$. Rozwija zatem u dzieci gotowość do odbioru sztuki.

Równie wnikliwej analizy tej metody dokonała B. Chrząstowska. Wdrażanie odkrywczego myślenia o przekładzie intersemiotycznym proponuje rozpocząć od wypracowania podstawowych pojęć. Do nich trzeba zaliczyć w pierwszym rzędzie pojęcie metody uwzględniajacej wszystkie uwarunkowania: strukture dzieta, rozwój osobowości ucznia i prawidtowości procesu dydaktycznego ${ }^{8}$. Ze struktury utworu można odczytać jego dyrektywy konkretyzacyjne, które projektują strategie odbioru dzieła literackiego: strategię odbioru emocjonalnego z uczniem w roli „czytelnika”, strategię odbioru przez działanie z uczniem w roli ,wykonawcy" oraz strategię opartą na analizie z uczniem w roli „badacza”. Aby kształcenie było wielostronne i zapewniało równowagę między emocją i intelektem nauczyciel, powinien zadbać o współwystępowanie tych strategii nawet $\mathrm{w}$ odbiorze jednego tekstu?

Obok struktury dzieła równie ważne jest uwzględnienie rozwoju osobowości ucznia: im młodszy czytelnik, tym częściej stosować trzeba strategię opartą na konkretnych działaniach. Wykonanie pozawerbalne prowokuje uczniów do aktywnego twórczego działania oraz przeżycia emocjonalnego utworu.

Założenie to wynika z podstawowych wymagań, jakie B. Chrząstowska stawia skutecznej metodzie. Oto pięć najistotniejszych zaleceń:

1. Elastyczność: nauczyciel na lekcji respektuje tekst literacki, jego eksplikację oraz poglądy uczniów, którzy stają się współtwórcami przebiegu zajęć.

2. Atrakcyjność: sposób podania i odbioru oraz praca z tekstem powinna budzić zainteresowanie, wyzwalać emocje i motywować do lektury.

3. Integralność: zapewnia łączenie różnych treści programowych i obejmuje różnorodne teksty kultury.

4. Konkretność: stwarza proste sytuacje, w których nawet treści abstrakcyjne mogą być łatwo przyswajane.

\footnotetext{
${ }^{7}$ Tamże, s. 17.

${ }^{8}$ B. Chrząstowska, Lektura i poetyka, Warszawa 1987, s. 199. W poetyce odbioru na podstawie rysunków dziecięcych wyróżniła B. Chrząstowska odbiór faktyczny, refleksyjny, symboliczny. Zilustrowała je analizując rysunkowe konkretyzacje wiersza S. Różewicza Bursztynowy ptaszek, zob. B. Chrząstowska, Lektura..., s. 129-140 oraz B. Crząstowska, Jak wprowadzić dzieci w świat poezji, [w:] B. Crząstowska, E. Polański, Nauczanie języka polskiego $w$ klasie 5, Warszawa 1985

${ }^{9}$ B. Chrząstowska, Lektura..., s. 209.
} 
5. Skuteczność: rozwija postawy twórcze ucznia, jego intelekt, wyobraźnię oraz sprawność językową, nie zapomina także o dziele. Praca „blisko tekstu” uczy dyscypliny myślenia i wypowiedzi. Kształtuje świadomość i kompetencje literackie $^{10}$.

Sprawne, świadome, refleksyjne posługiwanie się językiem i budowanie kultury literackiej jest zdaniem W. Żuchowskiej obszarem zapomnianym.

Sprawa pilna jest szukanie nowych sposobów motywowania uczniów do lektury, a w miejsce nauczania - tworzenie sytuacji uczenia się. I chyba nie ma innego wyjścia, jak czytanie aktywne, a więc takie, które zakłada od poczatku kontaktu $z$ utworem ekspresje $w$ innym tworzywie, czyli projektuje zadania $w$ formie dziatań, różnorodnych czynności angażujących nie tylko umyst. W pomyślnie przebiegajacej interpretacji utworu wiele bowiem zależy od nastawienia czytelnika. (...) W przektadzie intersemiotycznym dokonuje sie rekonstrukcji utworu pierwotnego, zachowuje się jego podstawowa ideę, wydobywa i uwyraźnia - właśnie dzięki innemu tworzywu - te jego warstwy i sensy, które wymykaja się gdzieś w odbiorze lub nie daja się uchwycić w ekspresji językowej, bo należa do tej „aury” słowa, która apeluje do różnych zmysłów, nie mieści się w warstwie czysto pojęciowej ${ }^{11}$.

W działaniach przekładowych zawarte są dwie perspektywy: utworu i ucznia. Uczeń wnikając w strukturę tekstu, uruchamia inne zmysły, inny rodzaj percepcji. Kiedy dokonuje wizualizacji utworu, ma ona charakter podmiotowy uczeń przedstawia utwór tak, jak go odebrał i dopełnił w konkretyzacji ${ }^{12}$.

W Żuchowska przestrzega jednocześnie przed zniekształconym rozumieniem metody przekładu intersemiotycznego.

Po pierwsze, działania zaplanowane w związku z lekturą testu nie mogą być prostym odwzorowaniem jakiegoś aspektu utworu. Nie jest przekładem ilustrowanie tego, co w utworze zobrazowane.

Po drugie, podmiotowy charakter lektury tekstu nie może się przekształcić w projekcję wnętrza odbiorcy i nie może naruszać autonomii i integralności dzieła. Jeśli się nie przestrzega tej zasady, metoda staje się zaprzeczeniem samej siebie i nie służy kształceniu umiejętności refleksyjnego czytania ani tym bardziej wzbogacaniu wnętrza czytelnika. Tekst nie może być pretekstem lub jedynie impulsem do działań, w których uczeń wyraża tylko samego siebie.

Po trzecie, korzystanie z tej metody doraźnie, okazjonalnie, może nie przynieść oczekiwanego, zadawalającego rezultatu.

Dopełniając te przestrogi i wskazówki W. Żuchowska podkreśla, że zaproponowana przed laty przez A. Baluch nazwa dla tego typu działań - „metoda pozawerbalna" - okazuje się zbyt pojemna: wbrew istocie koncepcji zagarnęła w praktyce wszelkie nie poprzedzone refleksja analityczną ilustrowanie, inscenizowanie, a także coraz popularniejszą dramę ${ }^{13}$.

\footnotetext{
${ }^{10}$ B. Chrzastowska, Lektura i poetyka...., s. 218.

${ }^{11}$ W. Żuchowska, Szansa w metodzie, „Nowa Polszczyzna” 1998, nr 2, s. 4.

${ }^{12}$ Tamże, s. 5.

${ }^{13}$ Tamże, s. 5-6.
} 
Ponieważ wokół przekładu jako metody pracy nad tekstem narosło sporo nieporozumień, przyjrzyjmy się drugiej perspektywie działań przekładowych: uczniowi w roli wykonawcy.

\section{Od ,mięśniowego wyczucia wiersza” do przekładu intersemiotycznego}

Badania Jana Polakowskiego, a później Tadeusza Patrzałka dotyczące naturalnego odbioru czytelniczego dzieci w młodszym wieku szkolnym prowadzą do wniosku, że dziecko czyta utwór literacki dla zaspokojenia potrzeb ludycznych i kompensacyjnych ${ }^{14}$.

Lubi rozpoznawać rzeczy dobrze znane $i$ dobrze się czuje wśród spraw swojskich. Zauważa konkrety - zdarzenia, szczegóty, postacie, nie ogarnia całości. Czyta z wtaściwym jego rozwojowi myśleniem subiektywnym, synkretycznym i fragmentarycznym - spostrzega $i$ zapamiętuje to, co chce, co je zainteresowato poprzez relacje do osobistych doświadczeń lub dowolnych skojarzeń; odbiór jest sita rzeczy naiwny i uproszczony ${ }^{15}$.

Kontynuację takiego sposobu myślenia odnaleźć można w badaniach A. Baluch. Analizując stopnie poetyckiej edukacji dzieci zauważa, że najmłodsze, mają - jak to określił Czukowski - „mięśniowe” poczucie wiersza.

Wiersz dziecięcy powstaje „od ruchu do dźwięku”, „od dźwięku do stowa”, czyli że „już po ich kadencji można poznać, że autor skakat, podskakiwat i tupat nogami. Wiersze dzieci zawsze powstaja podczas hopsania i podskakiwania ${ }^{16}$.

Dziecko i człowiek prymitywny nie potrafią wyrażać swoich uczuć i wzruszeń poprzez „prawdziwą poezję”. Wystarczy im podskakiwanie lub taniec, krzyk lub śpiew, zabawa lub rytuał, mówienie czy poezjowanie, a więc elementy reakcji naturalnych ${ }^{17}$.

Fundamentem tej refleksji literaturoznawczej stały się Piagetowskie badania zachowań dzieci oraz stworzona na podstawie ich wyników teoria procesów poznawczych. Biologiczne podejście Piageta - odkrywcze i empirycznie weryfikowalne - zyskawszy status kanonu, zamknęło na długo dociekliwość krytyczną. Niezamierzoną, choć nieuniknioną konsekwencją stała się uprosz-

\footnotetext{
${ }^{14}$ Por. na ten temat: J. Polakowski, Badania odbioru prozy artystycznej $w$ aspekcie dydaktycznym. Zarys teorii badań - próby diagnozy, Kraków 1980; T. Patrzałek, Postawy uczniów dziesięcioletnich wobec lektury, „Polonistyka” 1980, nr 6, a także Postawy uczniów jedenastoletnich wobec lektury, „Polonistyka” 1982, nr 3.

${ }^{15}$ W. Żuchowska, Oswajanie ze sztukq słowa. Poczqtki edukacji literackiej, Warszawa 1992, s. 55 .

${ }^{16}$ A. Baluch, Dziecko i świat przedstawiony, czyli tajemnice dziecięcej lektury, Wrocław 1994, s. 47.

${ }^{17}$ A. Baluch, Poezja wspótczesna w szkole podstawowej, Warszawa 1984, s. 12.
} 
czona adaptacja psychologiczna teorii Piageta na gruncie pedagogiki, zwłaszcza edukacji. Praktyka edukacyjna zdominowała dość powierzchownie odczytaną teorię Piageta ${ }^{18}$, zamknęła się, odcięła i na długo nie dostrzegała rangi nowego myślenia o zdolnościach poznawczych dzieci. W świadomości pedagogicznej teoria Piageta zakorzeniła się jako dogmat i mając status wyłączności determinuje charakter i kierunek programów i praktyki kształcenia.

Rodzą się jednak pytania: Jak to możliwe, że wrodzona, naturalna właściwość umysłu małego dziecka do rozumienia, a również tworzenia zaskakujących połączeń - w pewnej fazie rozwoju przypadającej na naukę wczesnoszkolną zanika, nawet obumiera. Czy procesy myślenia konkretno-obrazowego sq aż tak silne, że naktadaja się na zdolność myślenia abstrakcyjnego $i$ - dominując utrudniaja rozumienie treści abstrakcyjnych? Dlaczego „kryzys twórczy” (którego przyczyn upatruje się $w$ procesach przystosowania się do rzeczywistości) ma charakter tak głęboki $i$ nie jest zjawiskiem przejściowym a raczej utrwala się? Co dzieje się z umiejętnościami metaforyzacyjnymi? Dlaczego z wiekiem zamiast nasilać sie - słabna? Czy istnieja jakieś sposoby ich usprawniania? ${ }^{19}$. To są pytania wielkiej wagi, bo dotyczą nie samego języka, ale podstaw myślenia, więc nurtują baczy nie ze względów opisowych.

Badania prowadzone $w$ ramach nauk o poznaniu odsłoniły pewne aspekty uczenia się w relacji z nauczaniem: przyjmując, że uczenie się jest procesem zasadniczą rolę przypisuje się sposobowi udzielania instrukcji, a ściślej sposobowi organizowania sytuacji uczenia się. Dzięki wytworzonym na gruncie kognitywizmu koncepcjom rozwoju intelektualnego dokładniej znamy naturę uczenia się i rolę, jaką w tym rozwoju pełni nauczanie ${ }^{20}$.

Symptomy tego myślenia wydobywa przenikliwie J. Bruner w teorii dochodzenia do wiedzy podkreśla uniwersalny charakter procesów uczenia się: uważa, że mechanizmy u dorosłego i dziecka w istocie nie różnią się. Aktywność umysłowa uczonego i aktywność umysłowa dziecka rozwiązującego problem ma tę samą naturę - różnica jest w stopniu, a nie w rodzaju. Ze względu na konsekwencje dydaktyczne J. Bruner sformułował jedno z najdonioślejszych

${ }^{18}$ L. Witkowki w książce Edukacja wobec sporów o (po)nowoczesność, Warszawa 2007 upomina się o lekturę pracy J. Piageta Introduction a l'epistemologie genetique opublikowanej w roku 1949. W jego przekonaniu szczególnie interesującymi, choć niedoczytanymi przez filozofów, psychologów czy teoretyków kultury są następujące zagadnienia: decentracja jako wyzwanie w rozwoju jednostki i kultury, paradoks dualnej podmiotowości oraz cechy egocentryzmu strukturalnego.

${ }^{19} \mathrm{~W}$. Żuchowska, Zachować i rozwijać to, co naturalne. O pracy nad metaforq z młodszymi dziećmi, „Nowa Polszczyzna” 1997, nr 2, s. 9.

${ }^{20}$ M. Donaldson, Myślenie dzieci, Warszawa 1986; L. Eliot, Co tam się dzieje? Jak rozwija się mózg i umyst w pierwszych pięciu latach życia, Poznań 2003; A. Gopnik, A. N. Meltzoff, P. K. Kuhl, Naukowiec $w$ kotysce. Czego o umyśle uczq nas mate dzieci, przeł. E. Haman, P. Jackowski, Poznań 2004; D. Wood, Jak dzieci uczq się i myśla, przeł. R. Pawlik, A. Kowalcze-Pawlik, Kraków 2006. 
twierdzeń: nie ma wiedzy ,zbyt trudnej” dla ucznia, wszystkiego można nauczyć, nawet bardzo wcześnie, jeśli się znajdzie odpowiednią metodę ${ }^{21}$. Istnieje zatem konieczność pomagania wszystkim dzieciom w osiagnięciu optimum rozwoju (maksymalizm dydaktyczny) ${ }^{22}$. Dobrze zaprojektowane działania nauczyciela mogą więc pomóc dziecku w przejściu na wyższy poziom rozumienia utworu ${ }^{23}$. Podważają zasadność obiegowych przekonań o właściwej dzieciom w wieku wczesnoszkolnym infantylności. Zarazem potwierdzają słuszność kulturowego podejścia do procesów uczenia się:

Dziecko uczestniczy $w$ życiu spotecznym prawie na równi z dorostymi, ma dostęp niemal do wszystkiego, korzysta z podobnych co dorosty źródet informacji. Z pewnościq obchodzi je każdy szczegót codzienności, zauważa to, co obiegowe, rejestruje nowości, obserwuje zmienność rzeczy, dostrzega różnice między tym, co powszechne, a tym, co indywidualne i osobiste $e^{24}$.

Dla zamknięcia tej części rozważań problem można by sformułować następująco: wrodzona dyspozycja, naturalność łączenia rzeczy odległych, łatwość przenoszenia właściwości przedmiotu jednych na inne - dające się zaobserwować u małych dzieci - słabnie niećwiczona, zaniechana, niedoceniona. Jest w stanie przetrwać u niewielu dzieci w postaci „zahibernowanej”; jednak u ogółu można mówić o zaniku, przejściu w stan obcości, zapomnienia, całkowitego wyparcia ze świadomości. Nawet pobudzana kontekstem, zadaniem - nie pojawia się w horyzoncie domysłów, poszukiwań czy hipotez interpretacyjnych.

${ }^{21}$ Zob. J. S. Bruner, Proces ksztatcenia, Warszawa 1965.

${ }^{22}$ Tamże

${ }^{23}$ A. Baluch, Narracja stowna a znaki ikoniczne. Przektad obrazu literackiego na wypowiedź plastycznq, „Oświata i Wychowanie” $1982 \mathrm{~B}, \mathrm{nr} 17$ oraz A. Baluch, Dziecko i świat przedstawiony, czyli tajemnice dziecięcej lektury, Wrocław 1994, A. Baluch, Poezja wspótczesna w szkole podstawowej, Warszawa 1984; Por. także na ten temat: J. Polakowski, Metoda przektadu intersemiotycznego w kształceniu sprawności językowej, „Oświata i Wychowanie” 1982 B, nr 17 oraz A. Dyduchowa, Jak systemy znaków pozajęzykowych pomagaja w rozwijaniu sprawności mowy, [w:] Nauczanie języka polskiego w klasie 5, red. B. Chrząstowska i E. Polański, Warszawa 1985, s. 31-36. T. W. Weaver, G. M. Prince, Synektyka i jej znaczenie dla edukacji, [w:] Nieobecne dyskursy, cz. II, red. Z. Kwieciński, Toruń 1992, W. Limont, Myślenie metaforyczne i myślenie przez analogię „Ojczyzna-Polszczyzna” 1994, nr 4. W. Żuchowska, Oswajanie..., s. 165 oraz Zachować i rozwijać....

W literaturze polonistycznej przekład pozawerbalny jest jedną z metod kształcenia literackiego. Por. na ten temat artykuły w zeszycie: $Z$ dydaktyki literatury $i$ kultury $w$ szkole, red. E. Cyniak, Łódź 1994.

${ }^{24}$ B. Boniecka, Z dziecięcego punktu widzenia, „Annales Academiae Paedagogicae Cracoviensis" 2004, folia 19, s. 45 oraz D. Klus-Stańska, Wiedza ucznia w nauczaniu zintegrowanymod formalistyki do konstruowania znaczeń, [w:] Wczesna edukacja. Między schematem a poszukiwaniem nowych ujęć teoretyczno-badawczych, pod red. D. Klus-Stańska, E. Szatan, D. Bronk, Gdańsk 2006. 
Nic nie jest gotowe, ani też dane raz na zawsze. Dziecko jest w drodze, rozwija się, dlatego tak ważne jest pobudzanie jego wrodzonych dyspozycji w procesie edukacji. Każde rzeczywiste tu i teraz nieodwołalnie rzutuje w przyszłość i nic nie zwalnia dorosłych z odpowiedzialności za intensywność środowiska, które ma pobudzać i wzmacniać potencjalne możliwości wzrastającego człowieka. Proces kształcenia jest wspomaganiem rozwoju, nie można z nim czekać ani zwlekać, ponieważ połączenia neuronalne w mózgu nie pobudzane $\mathrm{z}$ zewnątrz, tracą bezpowrotnie swoje funkcje poznawcze ${ }^{25}$.

Przeszkody, które utrudniają wgląd w predyspozycje dzieci, są problemem badacza, a nie dzieci. Barierę stanowi dziecięca względna umiejętność werbalizacji procesów myślenia, ograniczona zdolność autoanalizy i autorefleksji. W jakimś stopniu tę barierę poznawczą znosi metoda pozawerbalna.

Metodę przekładu intersemiotycznego zastosowałam na przykładzie baśni. Do działania przekładowego na przykładzie baśni zainspirowało mnie myślenie Bruno Bettelheima: Baśn to elementarz, z którego dziecko uczy się czytać we wtasnym umyśle, elementarz napisany $w$ języku obrazów. Jest to jedyny język, dzięki któremu możemy rozumieć siebie i innych, zanim dojrzejemy intelektual$n i e^{26}$. Baśn stanowi typ lektury, z jaką dziecko styka się najwcześniej. Opowiadana lub czytana przez pośrednika, bądź też oglądana w wersji teatralnej czy filmowej, zaspokaja naturalne potrzeby dziecka, spełniając zarazem wielorakie funkcje poznawcze, wychowawcze i kształcące ${ }^{27}$.

Na podstawie tego niewielkich rozmiarów utworu o treści fantastycznej, nasyconej cudownościq zwiqzana $z$ wierzeniami magicznymi, ukazujacego dzieje ludzkich bohaterów swobodnie przekraczajacych granice między światem poddanym motywacjom realistycznym a sfera dziatania sit nadnaturalnych ${ }^{28}$, badałam, w jaki sposób dzieci odzwierciedlają schemat baśni w działaniach przekładowych.

W jaki sposób ujmują akcję baśni, która rozgrywa się w nieokreślonym miejscu i czasie oraz kategoryzują bohaterów baśni i motyw wędrówki.

Bohater baśniowy zazwyczaj zwyczajny, słaby, pokrzywdzony, opuszcza dom, czyli przestrzeń znaną, oswojoną, względnie bezpieczną i rozpoczyna wędrówkę. Napotyka na swej drodze wiele trudności, cierpień i przeciwności. Zwykle towarzyszy temu próba charakteru. W sytuacjach trudnych jest pełen samozaparcia, umie szukać pomocy i wie, jak korzystać z otrzymanych wskazówek. Ujawnia się wówczas wytrwałość, dobroć, dzielność

${ }^{25}$ Por. G. Dryden, J. Vos, Rewolucja w uczeniu, Poznań 2000.

${ }^{26} \mathrm{~B}$. Bettelheim, Cudowne i pożyteczne. $O$ znaczeniach $i$ wartościach baśni, t. 2, przeł. D. Danek, Warszawa 1985, s. 10.

${ }^{27}$ Z. Adamczykowa, Baśń z perspektywy szkolnej, [w:] Literatura dziecięca. Funkcje - kategorie - gatunki, Warszawa 2004, s. 169.

${ }^{28}$ Słownik terminów literackich, pod red. J. Sławiński, Wrocław, Warszawa, Kraków, Gdańsk 1976, s. 47. 
i spryt bohatera. Za swoją wytrwałość i dobroć otrzymuje nagrodę. Często w przezwyciężeniu trudności pomagają mu magiczne przedmioty jak: różdżka, siedmiomilowe buty, kije samobije, latający dywan czy czapka niewidka. Zgodnie ze schematem baśni świat realny przenika się z fantazją. Baśń doskonale ukazuje, że oba te światy mogą funkcjonować równocześnie bez zakłóceń i sprzeczności.

W badaniach interesowało mnie również, w jaki sposób dzieci utrwaliły w pracy zasadnicze elementy ludowego światopoglądu: wiarę w nieustającą ingerencję mocy pozaziemskich w życie ludzi, antropomorficzną wizję przyrody, niepisane normy moralne i przekonanie o triumfie dobra nad złem. W każdej baśni eksponuje się wartości moralne poprzez jednoznaczne pokazanie, kogo i za co spotyka nagroda lub kara. Kara i nagroda równoważą się; są one często nieproporcjonalne do czynów. Zło jest zawsze ukarane, nie ma współczucia dla sprawcy ani darowania win $^{29}$. Baśń zawiera optymizm, choć niełatwy:

- szczęście nie przychodzi samo, trzeba pomyślnie przejść próby charakteru,

- pomoc ze świata magicznego, jeśli się na nią zasłuży zachowaniem, postawa,

- życie jest pełne trudów, ale nagrodzone,

- wiara, że warto być dobrym,

- przekonanie, że dobro zwycięża.

Podsumowując, baśń zawiera podstawową wiedzę o świecie (życiu, człowieku), nie idealizuje rzeczywistości (niesprawiedliwość, krzywda, bieda, niebezpieczeństwa), obrazuje pokonywanie przeszkód i trudów, radzenie sobie z własną słabością, nabywanie samodzielności jako droga do dojrzałości, uzyskiwanie samoświadomości (kim jestem) oraz wyraża pragnienie świata, jaki mógłby (powinien) być.

Przedstawię część cyklu zdarzeń edukacyjnych, które zorganizowałam dla uczniów z trzecich klas szkoły podstawowej. Zajęcia sprawiły, że akt lektury stał się dla mnie i dla nich poruszającym doświadczeniem. Udało się wyzwolić w uczniach chęć i gotowość podjęcia wysiłku interpretacyjnego, a zarazem wprowadzić problematykę skłaniającą do myślenia abstrakcyjnego.

Zdecydowałam się na pracę nad baśnią „Dziewczynka z zapałkami”, która spełnia funkcję kompensacyjną, ponieważ dostarcza zastępczych przeżyć. Dzięki tej baśni likwidowane są negatywne napięcia, takie jak: strach, gniew, lęk. B. Bettelheim uważa, że rodzice zwykli ukrywać przed dziećmi, że w życiu bywa źle. Starają się przekonać dzieci, iż wszyscy ludzie są dobrzy, że zło nie istnieje. Baśń ukazuje dzieciom, że walka $\mathrm{z}$ poważnymi trudnościami jest w życiu nieunikniona, jest ona nieodłączną częścią istnienia ludzkiego - ale, jeśli się nie ucieka przed nią lecz niewzruszenie stawia czoło niespodzianym i często niesprawiedliwym ciosom, pokonuje się wszelkie przeszkody i w końcu odnosi zwycięstwo ${ }^{30}$.

\footnotetext{
${ }^{29}$ M. Molicka, Bajkoterapia. O lękach dzieci i nowej metodzie terapii, Poznań 2002, s. 141

${ }^{30}$ B. Bettelheim, Cudowne i pożyteczne....., s. 46.
} 


\section{Badanie działań przekładowych dzieci na przykładzie baśni}

\section{Cel badań}

Głównym celem badań uczyniłam analizę dziecięcych predyspozycji do rekonstruowania schematu baśni, zdolności rozumienia i rozpoznawania podstawowej idei baśni, umiejętności wydobycia i uwyraźnienia - właśnie dzięki innemu tworzywu - te jego warstwy i sensy, które wymykają się w odbiorze.

Przyjęłam, że badanie tych zdolności dzieci będzie miało również cel pragmatyczny. Poszukiwałam odpowiedzi na pytanie, czy rozwijanie predyspozycji wykonania utworu w innym tworzywie jest możliwe.

\section{Problematyka badań}

Wymienione pytania zakreślają obszary analizy zgromadzonego materiału. Uzyskane rozeznanie pozwoliło podjąć próbę wyjaśnienia:

1. Jak dzieci przełamują schemat myślenia konkretnego, aby oddać główną ideę baśni?

2. Jakie przesłanki pomagają im odróżnić wymiar symboliczny od wymiaru dosłownego?

3. W jaki sposób dzieci odzwierciedlają schemat baśni w działaniach przekładowych: bohatera, dom (przestrzeń znaną, oswojona), wędrówkę (niewiadoma, niebezpieczeństwa), przeszkody, próby charakteru, współistnienie świata realistycznego i fantastycznego (magii), otrzymanie zasłużonej nagrody?

4. W jaki sposób dzieci utrwaliły w działaniach przekładowych podstawową wiedzę o świecie (życiu, człowieku), nieidealizowanie rzeczywistości (niesprawiedliwość, krzywda, bieda, niebezpieczeństwa) oraz wyraziły pragnienie świata, jaki mógłby (powinien) być?

W celu zidentyfikowania znaczeń symbolicznych nadawanych przez dzieci określonym kategoriom i określenia ich umiejętności pod tym względem zaplanowałam przy użyciu różnorodnych metod, technik i narzędzi badania jakościowe i ilościowe ${ }^{31}$.

Badania przeprowadziłam w miejscu, które zapewnia dzieciom naturalne warunki uczenia się. Badaniami objęłam uczniów z klas trzecich łódzkiej szkoły podstawowej ${ }^{32}$. Liczebność wybranych klas była porównywalna (ok. 30 uczniów w każdej grupie).

${ }^{31}$ Zastosowałam klasyfikację metod opracowaną przez Stanisława Palkę. Por. S. Palka, Metodologia. Badania. Praktyka pedagogiczna, Gdańsk 2006, s.49-50.

${ }^{32}$ Badania przeprowadziłam w łódzkiej szkole: SP nr 56 przy ul. Turoszowskiej 10 w Łodzi. 


\section{Organizacja badań}

W éwiczeniach przekładowych opartych na kilku tekstach literackich pytania i polecenia nadały zasadniczy kierunek myśleniu i działaniu uczniów. Nie znaczy to, że należało oczekiwać od uczniów pełnego, dojrzałego odbioru dzieciom trudno byłoby zwerbalizować refleksję wysnutą $\mathrm{z}$ działania, ale działanie ułatwiające konkretyzację świata przedstawionego miało ku takiemu uogólnieniu prowadzić. Konkluzja wyłoniła się z rozmowy i refleksji nad wykonanymi pracami oraz z rozważań nad innością językowego ukształtowania świata w poznawanym tekście.

Tak zaplanowana i metodycznie zorganizowana praca (z zastosowaniem metody przekładu intersemiotycznego) umożliwiła wprowadzenie do świadomości dzieci problemów swoistego ukształtowania utworów literackich, jednak przede wszystkim teksty otworzyły przed dziećmi świat abstrakcyjnych zjawisk językowych.

Przebieg zajęć:

1. Opowiadam fragmenty baśni Hansa Christiana Andersena: „Dziewczynka z zapałkami”.

2. Podsuwam pomysł tworzenia $\mathrm{z}$ kawałków materiałów o kontrastowej fakturze (miękkie twarde) i odmiennych walorach kolorystycznych (jasne, łagodne, ciepłe - ciemne, zimne), a także o różnych kształtach bliższej i dalszej przestrzeni dziewczynki z zapałkami.

- Jak wyglądał dom dziewczynki? Spróbujcie go zbudować z dostępnych figur. Jakie ksztatty będą odpowiednie? Jakimi kolorami oraz materiałami wypełnicie mieszkanie dziewczynki?

- Jak się można czuć w takim otoczeniu?

- Jakie uczucia tam mieszkały?

- Jakich uczuć zabrakło w domu dziewczynki z zapałkami?

3. Inicjuję rozmowę wokół postaci występujących w utworze.

- Spróbujmy umiejscowić w przestrzeni domu figurki domowników: dziewczynki i ojca (duszę babci): dziewczynka - małe, białe koło; babcia -wielkie białe koło o miękkiej fakturze; ojciec - wielki czarny lub szary trójkąt; przechodnie - wielkie niebieskie trójkąty.

- W jaki sposób ustawicie figurki w przestrzeni domu: jak ulokowane są względem siebie, czy są obok siebie, czy są blisko siebie czy w oddaleniu?

- Aranżuję sytuację zachęcającą do transformacji wypowiedzi dzieci na czynności: uczniowie nanoszą odpowiednie kolory, aby pomalować świat na zewnątrz domu.

- Jaka na zewnątrz była pogoda?

- Jak zachowywali się ludzie?

- Co potęgowało cierpienie dziewczynki?

4. Zarysowuję sytuację problemową: $\mathrm{w}$ jakim celu dziewczynka wychodzi z domu w ostatni wieczór starego roku

- Jak przebiega jej wędrówka? Kiedy się rozpoczyna, kiedy się kończy? Jak długo trwa?

- Jakie spotykają ją przeszkody? (chodzi boso po śniegu: jeden bucik zgubiła, drugi zabrał chłopak, nikt nie zwraca na nią uwagi, przechodnie nie kupują zapałek, nie mając pieniędzy nie może wrócić do domu, ludzie spieszą się do domów, aby świętować)

- Kiedy i w jakiej sytuacji, w jakim miejscu poznajemy dziewczynkę? Jak się zachowywała? (czy narzekała na los, płakała, krzyczała, namawiała do zakupu zapałek, czy spokojnie wyczekiwała aż ktoś kupi zapałki)?

- Jakie sprawy, zjawiska przykuwają uwagę dziewczynki, dlaczego te właśnie? Co sobie wyobrażała, kiedy zapłonęły zapałki? O czym to świadczy? 
- Czy dziewczynka była samotna, czy może osamotniona w tłumie ludzi?

- Jak zakończyła się historia dziewczynki? Czy mimo wielu przeszkód, trudności i niebezpieczeństw wyprawa dziewczynki zakończyła się szczęśliwie?

6. Inicjuję rozmowę wokół artykułów prasowych: Dziewczynka z zapatkami, Utrzymuję mame

z tata, 200 milionów dzieci pracuje:

- Określcie charakter kłopotów dziewczynki z zapałkami i innych współczesnych dzieci zarabiających na życie, jak rozwiązać ich problemy, jak zaradzić zmartwieniom?

- Inicjujące rozmowę o tym, czy dzieci pracują, czy powinny zarabiać, jak jest w Polsce, jak na świecie, jak to oceniać, jakich rozwiązań szukają dorośli, co myślą o tym dzieci, jakich rozwiązań mogą szukać same dzieci?

\section{„Dotknięcie losu”, czyli co pokazały badania}

Realistyczna paraboliczność baśni Andersena „Dziewczynka z zapałkami” oswaja dzieci z antywzorami, a zarazem z koniecznym obiektywizmem w ocenie otaczającej nas rzeczywistości rodzinnych relacji. Dla zrozumienia tych kwestii ważne jest odtworzenie położenia i wyglądu domu dziewczynki z zapałkami oraz relacji między tym, co powinno dawać wnętrze i czym grozi świat zewnętrzny $^{33}$. Najbliższa i dalsza przestrzeń, powinna być jakimś centrum, miejscem, w którym się jest, z którego się wychodzi i do którego się wraca, dzięki obecności lub brakowi najbliższych powinna stać się przestrzenią uczłowieczoną.

Dzięki czynnościom wykonywanym na tekście uczniowie uwalniają skojarzenia oparte na kształtach, kolorach i fakturze. Próbują wizualizować dom, który nie jest prawdziwym domem oraz dostrzegać problemy dzieci dotkniętych losem i szukają dla nich rozwiązań. Zastosowana metoda przekładu intersemiotycznego daje możliwość niedosłownego wyrażenia za pomocą figur sensu baśni.

- „Białe kółko z waty to może być babcia, bo ono kojarzy mi się z niebem, ze śniegiem, z duchem, z ciepłem, (ch., III), z czymś miłym (dz., III), ciepłem, chmurą" (ch., III),

- „Żółte kółko, to może być dziewczynka, bo ona nie była zła, tylko chciała dobrze, a koło jest łagodne właśnie” (ch., III), - „A dla mnie nie pasuje, bo mi się koło ze słońcem kojarzy, jakby było jej ciepło, a na odwrót było jej zimno, tam wcale słońca nie było” (ch., III), - „A mi pasuje to małe kółko takiego koloru, bo jest takie lekkie a dziewczynka była mała i lekko ubrana" (dz., III), - „Tata będzie dużym czarnym trójkątem, bo on był bardzo zły dla niej” (dz., III).

\footnotetext{
${ }^{33}$ Istotę takiego ujęcia domu wyjaśnia G. Bachelard, Dom oniryczny i dom rodzinny, [w:] Wyobraźnia poetycka, Warszawa 1975.
} 
Dom dziewczynki przestaje być bezpieczną przestrzenią, nie można zrealizować w nim elementarnych potrzeb egzystencjalnych: ogrzać się, najeść, doświadczyć życzliwości ojca. W stworzonym przez siebie pracach dzieci próbowały wizualizować zimno doświadczane fizycznie oraz emocjonalnie, ciasnotę i ciemność domu głównej bohaterki.

- „Tata jest daleko od dziewczynki, bo w ważnych sprawach nigdy się nie zbliżał do niej, a babcia jest nad dziewczynką, bo babcia jakby czuwa nad nią, babcia ją chroni. Tutaj gdzie tata był jest na czarno pomalowane, bo panowała tam złość, a tam gdzie babcia to było miło i spokojnie dla dziewczynki" (ch., III),

- „Tata jest daleko od dziewczynki, a babcia jest pośrodku dlatego, że jakby babcia ich oddziela od siebie, żeby tata nie krzyczał na dziewczynkę, no i żeby dziewczynka nie płakała. Dziewczynka i babcia się kochały, dlatego zrobiłem tło na czerwono, a tata to zły, dlatego na ciemno" (ch., III)

- „W domu umieściłam tatę z boku i pomalowałam na czarno, dlatego że z nim czuła się dziewczynka smutno i źle. A kiedy była z babcią czuła się jak w raju"(dz., III),

- „W domu dziewczynki, gdzie stoi tata były takie ciemne kolory, bo tata był dla niej zły. A tutaj gdzie jest duch babci są żółte kolory. A tu zrobiłem takie błękitne, szare tło, bo w niebie było jej jeszcze lepiej” (ch., III)

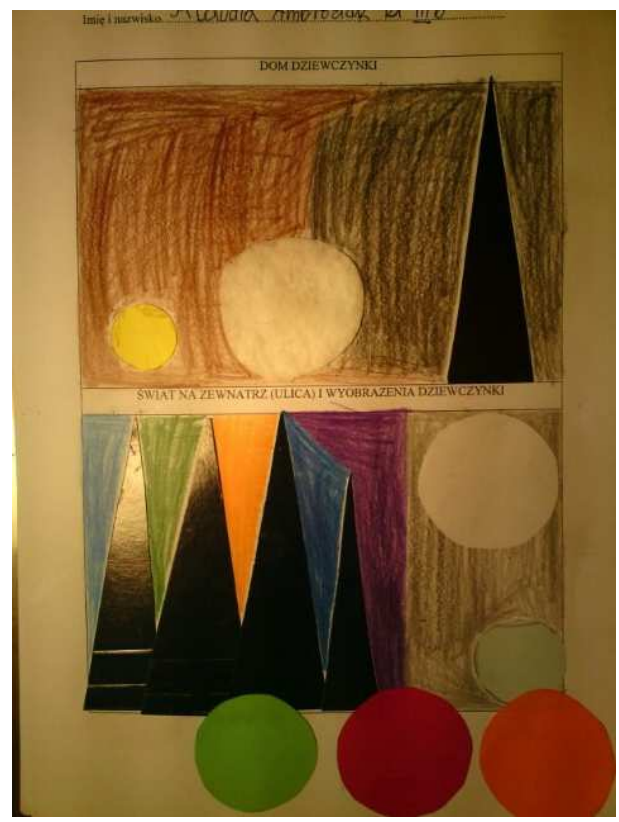

Rys.1. Konkretyzacja plastyczna przestrzeni domu i świata zewnętrznego (dz., III) 


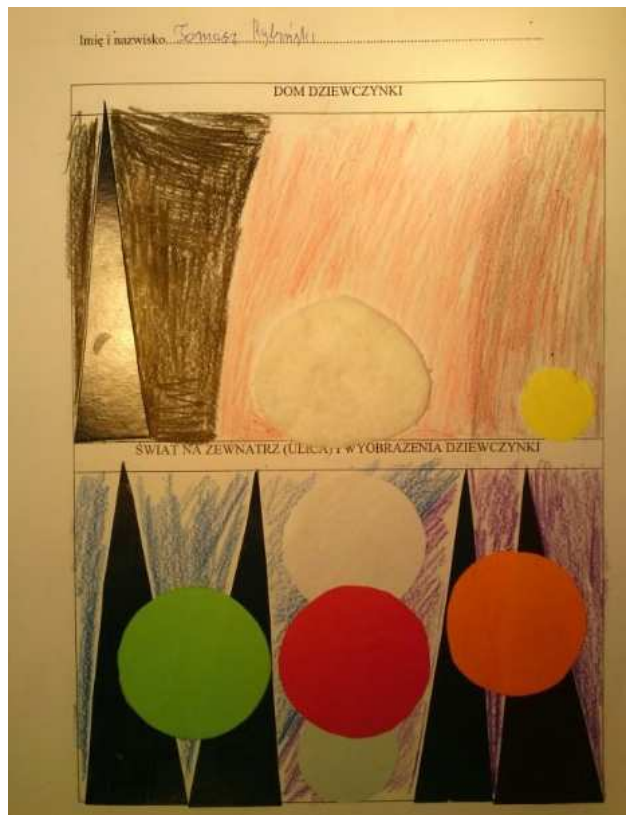

Rys. 2. Konkretyzacja plastyczna przestrzeni domu i świata zewnętrznego (ch., III)

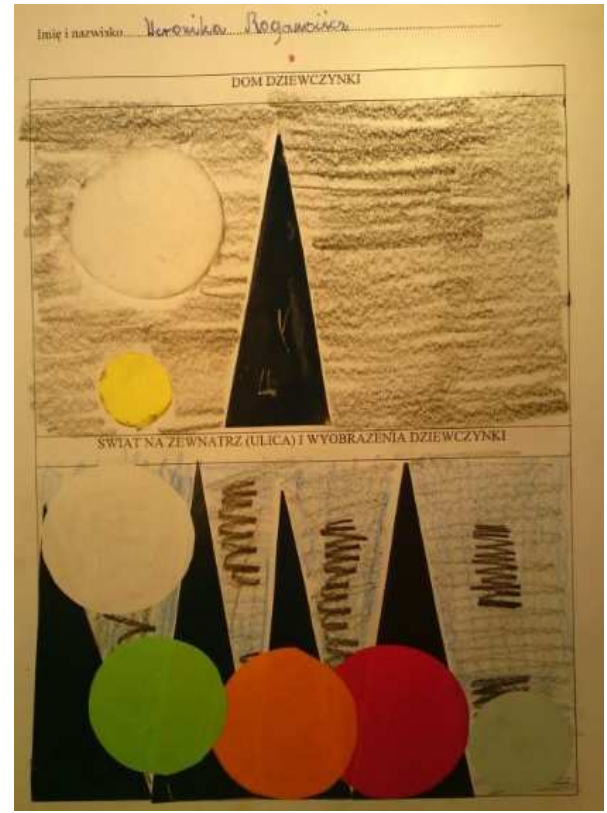

Rys. 3 Konkretyzacja plastyczna przestrzeni domu i świata zewnętrznego (dz., III) 


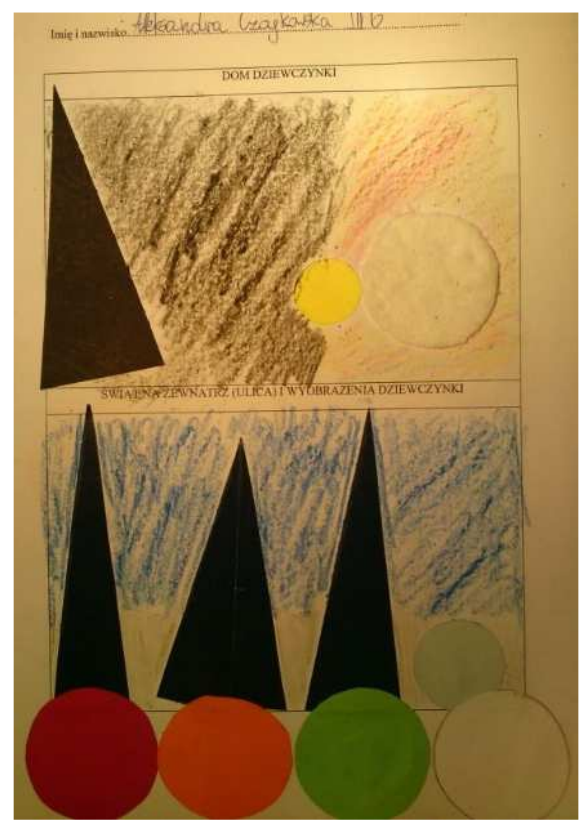

Rys. 4. Konkretyzacja plastyczna przestrzeni domu i świata zewnętrznego (dz., III)

Przez konkretyzację plastyczną uczniowie próbują określić charakter wędrówki dziewczynki, baśń rejestruje biegnące myśli, uporczywe pragnienia, które trudno zaspokoić. Głód, zimno, brak domu, brak rodziny, brak miłości, nieobecność bliskiej osoby, wywołują ,prześladowcze” myśli. Zdarzenia tworzą i rozwijają fabułę w sensie dramatycznym.

- „Na zewnątrz większą część zaznaczyłem na czarno, a tutaj na pomarańczowo na taki szczęśliwy kolor, bo ludzie cieszyli się z powodu Wigilii” (ch., III),

- „Ludzi umieściłem właśnie tak dlatego, że jakby szli w parach: pan z panią i pan z panią. Dziewczynkę umieściłem na środku, dlatego żeby ją było widać. Babcię na górze, bo babcia była tutaj najważniejsza jakby. Obok babci kaczkę i piec kaflowy, bo dziewczynka potrzebowała jedzenia i ciepła, choinkę umieściłem tak, że ona była tutaj najmniej ważna, więc jest najniżej. Tło zaznaczyłem fioletowym i niebieskim, dlatego że tam było wtedy zimno, a to są kolory bardziej zimne niż ciepłe" (ch., III),

- „Umieściłam wyobrażenia dziewczynki na ludziach, dlatego że jakby zapomina o ludziach, którzy byli źli. Kolory zimne, bo było zimno i szaro. Dziewczynkę umieściłam z boku" (dz., III).

Główna konstatacja, jaką można wyprowadzić z wypowiedzi dziecięcych: dla dziewczynki z zapałkami przestrzeń domu i przestrzeń świata zewnętrznego 
są nieprzewidywalne, nie dają poczucia bezpieczeństwa, uzależniają od innych, nie zapewniają swobody decyzji, ograniczają.

- „Ojciec zmuszał dziewczynkę, żeby sprzedawała zapałki (ch., III), „Wykorzystywał ją” (ch., III), „Był złośliwy, kazał jej pracować, a sam nie chciał” (dz., III),

- „Dziewczynka czuła się jak służący, bo ciągle robiła to, co jej tata kazał” (ch., III), ,Jak niewolnik się czuła” (ch., III),

- „Bała się postawić tacie, bo wiedziała, że będzie zły na nią” (ch., III).

W rozumieniu dzieci biedę możemy znosić godnie, ale możemy sobie z nią nie radzić, możemy udawać, że nas nie dotyczy:

- „Dziewczynka siedziała na zimnie i nie skarżyła się, nie krzyczała, wyobrażała sobie tylko różne rzeczy, żeby zapomnieć o swojej sytuacji” (ch., III).

Jakie przeszła próby charakteru, ile wysiłku i dobrej woli wykazała, by powściaggnąć swoje skłonności, nie dać upustu naturalnie w tej sytuacji odczuwanemu gniewowi, poczuciu krzywdy i niesprawiedliwości, podporządkować się decyzjom starszych. Dziewczynka jest głodna i przemarznięta, przez cały dzień nie sprzedała ani jednej zapałki, nikt nie ofiarował jej nawet grosika, zapada wieczór - nie może wrócić do domu, spaliła przecież zapałki, które miała sprzedać. Zrezygnowana usiadła w kącie między dwoma domami. Świat na zewnątrz zredukowany został do tego, co rejestruje wzrok: ciepłe światła w oknach obcych domów, kolorowo ubrane choinki oraz sfery zapachów: ulica przepełniona aromatem pieczonej gęsi.

- „Ludzie się zachowali tak bezinteresownie, bo taką biedną osobą wcale się nie interesowali, jakby nikogo nie było z boku" (ch., III),

- „Nawet nie chcieli spojrzeć na te zapałki. Od takiej osoby, co wyglądała na bezdomna, nic nie chcieli kupić" (ch., III),

- „Bo to było tak, że od biednej dziewczynki nic nie chce się kupić, bo może te zapałki by się raczej nie zapaliły albo by były wypalone” (ch., III).

To, co na zewnątrz - grudniowy wieczór świąt, przechodnie spieszący do domów - jest daremną próbą zajęcia uwagi, usiłowaniem odwrócenia myśli i wypełnienia nieznośnego głodu i uczucia zimna czynnościami zastępczymi. Wyliczanie na przemian uporczywych pragnień ginących wraz z ogniem zapałek wyraża subiektywnie odczuwane udręczenie, charakteryzuje męczącą uciążliwość. Monotonia wyliczeń i powtórzeń oddaje wydłużanie się czasu, co czyni trudną sytuację aż nie do zniesienia przykrą.

Zebrany materiał, skonfrontowany z obserwacją powszechnie stosowanych procedur edukacyjnych, pozwolił mi na wyciągnięcie wniosków służących praktyce edukacyjnej. Głównymi bohaterami tej pracy są dzieci, a ja - udzielając 
im głosu - podejmuję próbę obalenia mitu o infantylności ich myślenia. Warto wsłuchiwać się w wypowiedzi dzieci z pozycji kompetentnego użytkownika języka i wrażliwego słuchacza.

MONIKA WIŚNIEWSKA-KIN

\section{The potential educational of the translation method - proposition for teachers}

The bibliography about the method of translation is very rich. There are a lot of definitions of this method I chose four approaches of Jan Polakowski, Alicja Baluch, Bożena Chrząstowska and Wiesława Żuchowska. The method of translation I applied on example of a fairy tale. The main aim of my research was the analysis of children's skills to reflect the scheme of a fairy tale, also their skills to understand and recognize the main idea of a fairy tale.

Thanks to working on the text of the fairy tale children were talking about the associations based on shape, colour, texture. They tried to build the home for the main heroine of the tale and also they tried to perceive other children's problems and find the solution to the problems. 